\title{
THE USE OF LIMINALITY IN THE DECONSTRUCTION OF WOMEN'S ROLES: RUDOLFO ANAYA'S BLESS ME, ULTIMA
}

\author{
Isabel Gil Naveira, Universidad de Oviedo \\ Email: isabelgilnaveira@gmail.com
}

\begin{abstract}
During the 1970s Chicana feminist movement, Chicanas rejected the widely established image of the Virgin of Guadalupe vs. Malinche, which limited the liminal position they were claiming. In this essay I will examine Rudolfo Anaya's treatment of female characters in his novel Bless Me, Ultima (1972), bringing to light the latent disruption of this duality. It is my contention that Anaya's aim is establishing a dialogue between the self and the other(s) through liminal practices, spaces and times, which leads to a transformation of liminality into new opportunities for female characters in novels and hence to a deconstruction of Chicanas' roles in society.
\end{abstract}

Keywords: liminality; deconstruction; Virgin; Malinche; Chicanas; gender roles.

Resumen: Durante el movimiento feminista de las chicanas en los años 70, las chicanas rechazaron la ampliamente establecida imagen de la Virgen de Guadalupe frente a Malinche, que limitaba la posición liminal que reclamaban. En este artículo examinaré el tratamiento de los personajes femeninos de Rudolfo Anaya en su novela Bless me, Ultima (1972), sacando a la luz la latente alteración de esta dualidad. En mi opinión el objetivo de Anaya es establecer un diálogo entre el yo y la otra/las otras a través de prácticas, espacios y tiempos liminales, lo que lleva a una trasformación de la liminalidad en nuevas oportunidades para los personajes femeninos de las novelas y por ello a una deconstrucción de los roles de las chicanas en la sociedad.

Palabras clave: liminalidad; deconstrucción; Virgen; Malinche; Chicanas; roles de género.

\section{INTRODUCTION}

Two of the most representative female mythical figures within Mexican Culture are the Virgin of Guadalupe and Malinche. The Virgin of Guadalupe represents "a vision of the Virgin Mary that appeared to an Indian convert in the sixteenth century" in Mexico, whereas Malinche is "the Indian woman who served as Hernán Cortés's translator, negotiator, and mistress during the Conquest of Mexico" (Annenberg Foundation). These figures not only "have been manipulated and restructured to meet the political and spiritual needs of different cultural moments in Mexican history" (Annenberg Foundation), but they have been used to restrain the role of women in society. As Johnson collects, 
Western thought, says Derrida, has always been structured in terms of dichotomies or polarities: good vs. evil ... identity vs. difference ... man vs. woman ... These polar opposites do not, however, stand as independent and equal entities. The second term in each pair is considered the negative, corrupt, undesirable version of the first, a fall away from it (2004: viii).

Similarly, Mexican women have traditionally been provided with two polar images, Malinche-the negative and undesirable option-and the Virgin-the positive and desirable one-as the only possible roles they can play, forcing them to identify themselves either as virgins or as prostitutes. Critics have persistently shown for decades now that there is more to these two figures than a simple duality ${ }^{1}$.

During the 1960s Chicano civil rights movement, Chicanas "[were] involved on behalf of the communities they represented and on their own behalf to speak about their community needs and their own needs as women" (Cotera 1997: 229). Chicanas rejected the sexist attitudes they suffered in both Chicano and American societies, and some even claimed that Chicano society was very much swayed by the Mexican society in its patriarchal traditional set of ideas. ${ }^{2}$ In this way, Chicanas were relegated " "to be home' ... Confined to the space of the house, for lack of money or excessive zeal of their husbands or fathers" (Morillas Sánchez 2000: 274).

In the 1970s, the Chicana feminist movement highlighted their liminal position inbetween the American and Chicano societies. Because we deal with women who live in the United States, it is relevant to take into account not only Chicana feminism but also the Western concept of feminism present in the 1990s, when the Chicana writers' claims reached a wider audience. This Western feminism was described as:

a political perception based on two fundamental premises: (1) that gender difference is the foundation of a structural inequality between women and men, ... and (2) that the inequality between the sexes ... is produced by the cultural construction of gender differences. [Thus,] feminism [had] to understand the social and psychic mechanisms that construct and perpetuate gender inequality and then to change them (Morris 1995: 1).

Although this fighting is common to women from different contexts, I bear in mind the case of Chicanas as a special one due to their racial, migrant and low-class status. "Like white feminism, Chicana feminism originates in the community and on the streets as political activism to end the oppression of women" (Yarbro-Bejarano 1996: 213), nevertheless, Chicana writers like Sandra Cisneros emphasise Chicana feminism is "very much tied into [their] class" (Jussawalla and Dasenback 1997: 228). Hence, in my understanding of Chicano society as a postcolonial one, I distinguish how Chicanas have fought against

1 See Cordelia Candelaria "La Malinche, Feminist Prototype" (2002: 1-14) and Norma Alarcón "Chicana's Feminist Literature: A Re-Vision Through Malintzin/ or Malintzin: Putting the Flesh Back on the Object” (1981: 182-190).

2 According to Cotera, "Chicanas have been remarkably restrained about accusing Chicanos publicly of discrimination and imposing barriers. And yet the Chicanas' growth is often stultified at home with fathers, brothers, and husbands ... Often their conservatism comes from belief in the macho myths spread by university sociologists in the $1930 \mathrm{~s} . .$. [and] from ignorance about the roles that women have played in history and in the community" (231) 
gender difference and inequality, but have also considered other factors like race, class, culture, ethnicity, role and sexual orientation.

The well-established dichotomy of the Virgin vs. Malinche is also thoroughly present in the artistic representations of the Chicano society. Both figures represent the dominant and fixed identities that society established for women, hence they usually appear in Chicano (patriarchal) literature and Chicana literature as characters or icons female characters can be easily identified with. In this essay I will examine Rudolfo Anaya' treatment of female characters in his almost autobiographical novel Bless me, Ultima (1972) as a case study of feminist writing by a Chicano author. For this I will consider the role of literature as a tool to represent society and bear in mind that "the study of literary sources ... [provides us] with the biographical account as a personal point of view to get closer to social problems"3 (Benítez Eyzaguirre 2008, my translation).

The narrator of the novel is Antonio, a seven-year-old boy who recalls part of his childhood in the village of Guadalupe, New Mexico. As a child, Antonio must learn how to mediate with the differences that arise in most aspects of his life-not only as a Chicano in the Anglo world, but also in his family and in religion. Since "social responsibility must be the basis of any theorizing on postcolonial literature as well as the root of the creative work of the writers themselves" (Katrak 1995: 255), it is interesting to analyse how Anaya describes-through Antonio's eyes-the women who surround him. In this way, he highlights the social establishments of the village and provides the reader with a supposedly innocent vision of women's roles in a Chicano patriarchal community.

This novel has been traditionally addressed as a coming-of-age account (Klein 1992) and also as a religious, ritualistic and mythological novel (Holton 1995; Beekman Taylor 1997; Kárai 2008). Nonetheless, hardly ever is the role of women analysed. Jane Rogers (1977) paid attention to its female characters in comparison to La Llorona myth; and although it is true that the figure of La Llorona, "read by Chicana feminist critics as heavily misogynistic in its traditional form" (Caminero-Santangelo 1999: 21), is present in the novel, there are also other characters that do not follow this pattern ${ }^{4}$.

Anaya's female characters can be classically grouped in two categories, following the established opposites of good vs. evil. On one side of the dichotomy Anaya includes Maria Luna (Antonio's mother) and the Virgin of Guadalupe and, on the other side, Anaya presents the reader with some prostitutes and three witches. Ultima, the main female character of the novel, does not seem to fit in any of these standardised dual roles. Juan Antonio Perles Rochel described the novel as a phallocentric and patriarchal construction that presented "as 'universal' a strong androcentric vision of the world" (1994: 206, my translation). He acknowledged that a feminist reader could be tempted to consider the remaining female

3 "El estudio de fuentes literarias, habitualmente dentro de la línea de investigación de la etnografía y la antropología social ... aportan ... las interpretaciones subjetivas del imaginario social ... [y] el relato biográfico como un punto de vista propio para el acercamiento a los problemas sociales" (Benítez Eyzaguirre). The translation is mine.

4 It is not the first time Anaya portrays female figures in positive terms. See his storybooks for children Maya's Children: The story of La Llorona (1984) or La Llorona: The Crying Woman (2011), where he portrays La Llorona as a sympathetic figure, and The Legend of La Llorona, a Short Novel (1984), where Anaya establishes a link between La Llorona and Malinche, presenting Malinche as the first Llorona and leaving aside the negative images of traditional myth. 
character, Ultima, as a feminist figure, however he dismissed this idea on the basis that she does housework, promulgates patriarchal ideas to Antonio and criticizes the attitude of the three witches. What Perles Rochel seems to leave aside is the fact that the character of Ultima is a curandera, a 'healer' whose practices and the spaces she inhabits do not follow a traditional patriarchal role for women. Moreover, this character does not just reflect single characteristics of a Virgin-like character or single characteristics of a Malinche-like one. For these reasons, I see the need to analyse the role of Anaya's female characters more deeply, paying attention to the question of liminality and to the deconstruction of women's roles that it entails.

In her analysis of Derrida's idea of deconstruction, Barbara Johnson emphasises "the word 'de-construction' is closely related not to the word 'destruction' but to the word "analysis"" (2004: xv). In the 1970s, Chicano narrative "sought to elaborate new agency and representation strategies, it looked for heroes and viable relations to the communities they represent" (Karrer 2001: 141), and therefore I believe in his novel Anaya reverses society by highlighting what in society usually remains in the margins or unspoken. In this way, Anaya's use of characters and the relation he establishes between the novel and its social context follows Derrida's idea of deconstruction as something that "involves an indispensable phase of reversal" (2004: 5).

Through the trope of liminality, borrowed from anthropology, I will analyse the coexistence between traditional female roles and liminal figures, that have led Chicana authors and critics, like Cherrie Moraga, Norma Alarcón, Gloria Anzaldúa and Ana Castillo among others, to the deconstruction and redefinition of women's roles in a patriarchal society. The term liminality, from the Latin word limen, 'a threshold', is usually defined as "a borderland state of ambiguity and indeterminacy, a transformational state characterized by a certain openness and relaxation of rules, leading those who participate in the process to new perspectives and possibilities" (Gilsenan Nordin and Holmsten 2009: 7).

Although the concept of liminality was first described by Van Gennep (1960), ${ }^{5}$ it was Turner the one who developed it. Van Gennep's concept of liminality is the interstitial stage in the process of ritual initiation, being liminality a phase in-between the separation step and the reaggregation or reassimilation step. While Van Gennep's liminality is supposed to have a final stage or space in which the subject rejoins society after their liminal phase, Turner's idea of liminality is something more durable, not just a phase but a state that can be permanent.

Turner's concept of liminality leaves the door open for its application to other areas of thought, hence, following his interpretation of liminality "as a realm of pure possibility whence novel configurations of ideas and relations may arise" (1967: 97), I understand liminality as a state of in-betweenness and ambiguity that some characters in novels can appropriate. For Turner "the features of liminality are ambiguous; that is, they are outside of all society's standard classification" (1967: 94). Moreover, he adduces liminal characters are outside of the ordinary flow of time (1969), what also provides them certain ambiguity. For these reasons, I will follow Turner's theory in my contention that Anaya's aim, by

5 Van Gennep's Les rites de passage was published in 1909, although his influence in anthropological studies was in the mid-19th century and his work was published in English in 1960. 
using the female characters in this novel, is establishing a dialogue between the self and the other(s), understanding the other(s) as the dual roles of the Virgin and Malinche established in many novels. This dialogue will take place through the liminal practices, spaces and times, which are used and made meaningful in literature, leading to a transformation of liminality into new opportunities for female characters in novels and hence to a deconstruction of Chicanas' roles in society.

\section{VIRGIN-LIKE CHARACTERS}

When describing the 'good' side of the dichotomy it is necessary to consider that in traditional Chicano fiction women are usually associated to their role as daughters, wives and mothers, "relegated to the household chores [and] confined to the loneliness of the house because that is the decent thing to do" (Morillas Sánchez 2000: 273, 275). This type of woman is "to be the hearth of the home; to be chaste, modest, honorable, clean and more importantly, to minister to the needs of her husband and children" (Mirandé and Enríquez 1979: 98); this is what represents her as a woman, establishing her role in society and her identity.

Following this traditional patriarchal establishment, Anaya presents the reader with two different characters, Maria Luna (Antonio's mother) and the Virgin of Guadalupe. In the very first page of the novel Anaya establishes Maria Luna's role as mother and wife; highlighting that even her son contributes to this role, as he describes the kitchen in their house as "the heart of [their] home, [his] mother's kitchen" (Anaya 1994: 1). Maria is also a woman devoted to the Virgin, "a devout Catholic, [who] saw the salvation of the soul rooted in the Holy Mother Church" (29). She prays for Antonio to become a priest, as for her a "community of farmers ruled over by a priest ... was the true way of life" (29); and her faith leads her to keep an altar for the Virgin at home, "her altar" (43) as Antonio describes it.

Maria's devotion is a priority for her as she even delays preparing supper, one of her duties as wife and mother, in favour of praying. Moreover, when the war ends and she knows her elder sons will come back home, her religious nature is almost described as an obsession. Maria thanks every saint she knows, above all the Virgin of Guadalupe, and makes the whole family pray "rosary after rosary" (60) during the whole night. When they arrive, hardly has she welcomed them that she forces the whole family to pray again and, despite her husband complains for having been praying all night long, they all "had to kneel for one more prayer" (63).

Anaya's vision of a traditional mother stays unmovable throughout the novel and the only change is her relationship with Antonio. Maria's situation as a woman subordinated to her family through her role as wife and mother is accepted by society, and therefore by her as well, to deteriorate. The moment her son grows she no longer has authority as a mother, what relegates her to the role of wife. At the end of the story, although he is still a boy, Antonio speaks to his mother as a man, imposing his will on hers, and Maria, following her social role, simply "nod[s] and obey[s]" (259) without questioning him or his authority.

Interestingly, Antonio, in one of his dreams, sees his mother and identifies her with the Virgin. In this way, both figures are connected and their role is established as representatives of the good and saint woman, the nurturing and caring mother figure. The first reference 
to the Virgin of Guadalupe comes with the name of the town, which is named after her, Guadalupe; consequently, the Virgin-mentioned or not-is present at every time.

Antonio's devotion to the Virgin is very strong, not only does he describe her as "the queen of heaven" (43), but he always turns to her in his search for answers and acknowledges that, "although there were many other good saints, [he] loved none as dearly as the Virgin"6 (44). The delicate and warming figure Antonio refers to when describing the Virgin contrasts with the harsh and fearsome one he uses for describing God. The reader is presented with a woman with positive, pious characteristics: she always forgives; she is full of quiet, peaceful love; her voice is sweet and gentle; she could persuade God to forgive somebody; her soul is without blemish; and she was born without sin.

On the contrary, God is described as a giant, not always forgiving, powerful man who speaks through thunders. This can be interpreted as the vision of a child who is still under the protection of the female figures within his family and for whom the world of men he will grow up into is still unknown and, therefore, mysterious and frightening; but in fact, this image of the Virgin promotes the patriarchal ideal of the good woman.

Antonio's notion that the Virgin is the perfect goddess, due to her forgiving nature, is repeated in several occasions. However, the moment he wants his brother's sins to be forgiven but not his enemy's sins-Tenorio's-there is a change in Antonio's attitude towards the Virgin, who does not seem to be the perfect goddess any longer. In spite of this lack of understanding, Antonio keeps on praying to the Virgin, with whom he establishes a connection again as he "felt as if she listened, like [his] mother listened" (187).

In both cases, Maria Luna's and the Virgin's, their role is already established. The Chicano society they live in presents them as women who always listen, always pray and are always there for their children and family, but who cannot take decisions. The spaces and times they inhabit are also established by society and do not present any liminal characteristic. While the house and the church are the only 'proper' spaces they are allowed to occupy, their tradition connects them to the past, rather than to the present and the future, thus constraining their identity and their social role to those of mother and wife.

\section{MALINCHE-LIKE CHARACTERS}

The opposite side of the dichotomy presents the reader with the prostitutes and the three witches, the Trementina sisters. Although they contrast with the benevolent images of the mother and the Virgin analysed, I will argue they share with them an already established and fixed identity. It is society, once again, the one that tries to determine their roles and prevent them from contravening them.

The prostitutes and the brothel are related to Antonio's loss of innocence. It is important to take into account Antonio's position as a child, as all he knows comes through the ideas and comments he hears, above all when talking about a part of life he is still unaware of. The image Anaya's narrator has of prostitutes is influenced by his friend Florence's explanation

6 According to Rose Anna Pentecost "[t]he multiple connections of La Virgen de Guadalupe to the indigenous worship would explain the devotion of Mexicans to the Virgin" (2014: 46). This devotion could also be extended to Chicanos. 
about his parents' death and his sisters being "whores, working at Rosie's place" (195). At this point being a prostitute is presented not only as something negative, but as something worse than death. In addition, with Antonio's description of a prostitute doing the laundry as a young girl who was "hanging out brightly colored garments" (47), Anaya compares the girls at Rosie's colourful garments with the black colour used by many of the women in town, who had lost husbands and sons in war. Furthermore, presenting the girl as someone who "was soon lost in the furrow of dust the truck raised" (47), he establishes the religious idea that they were lost girls, fallen women, and therefore, clear representations of Malinche.

The only time the reader can actually analyse Rosie's attitude, instead of finding people's ideas about her, she appears yelling: "'You are drunk! Or mad! Or both!' the woman shouted" (164). The description provided of her as a woman whose "face was painted red, and ... her teeth were shiny white. Her sweet perfume wafted through the open door and mixed with the music from within" (164) contributes to establishing a contrast between her and the Virgin-like women in town, highlighting her situation as 'the other'.

This same image is repeated when Antonio describes the girl with whom his brother spends his time at the brothel: "She was dressed in a flowing robe ... so loose it exposed her pink shoulders and the soft cleft of curving breasts" (165). Although this prostitute has a voice, Anaya emphasises her attitude as plain and repetitive, stressing the idea that she was only interested in keeping men at the brothel:

'Tell him to go away and close the door,' the girl giggled. ... 'Shut the door! It's cold!' the girl whimpered. ... 'Come in, Andrew,' she pleaded. ... 'Close the door, Andrew,' the girl begged, 'only fools and drunks would be out in that storm' (166).

For Antonio, Rosie, the owner of the brothel, represents evil, but "not evil like a witch, but evil in other ways" (34). Despite the fact that all of them are Malinche-like characters, this sentence shows a contrast between the evil Rosie and the other prostitutes represent and the evil of the three Trementina sisters. The first reference to these so-called witches who enact black magic is made by Antonio, who explains that "[a]cross the river in the grove of trees the witches danced ... with the Devil" (50). Stories about witches were commonly told around the fire at his grandfather's house; and elements such as the owl and the coyote usually appeared associated to their black magic. The figure of the witch was usually related to old women and it was also common knowledge that "under the old law there was no penalty for killing a witch" (87), so anyone could accuse and kill a woman who, according to their perspective, did not have an appropriate, Catholic behaviour.

The Trementina sisters are accused in the novel of putting a curse on one of Antonio's uncles because he "had seen [them] do their evil dance for el Diablo" (84). Even though no proof of their deeds is given, no proof is needed either. On the one hand, Antonio's uncle describes how he "thought [my emphasis] the three witches were three old dirty women who deserved a Christian lashing ... so he challenged them! ... '¡Oye ['Hey']! You ugly brujas ['witches'], prepare to meet a Christian soul!'” (88), being his word enough for the family to believe him. On the other hand, the family thinks the witches responsible for the dance were Tenorio's daughters, as the image they have of their father is that of an evil 
man and their mother "was known to make clay dolls and prick them with needles ... [and some people] died from her curses" (88).

Because accusing a woman of witchcraft was simple and no proof confirming the crime was needed, a great part of the village believes the spread word. And the general idea about the Trementina sisters conforms with the description of a witch:

women who long ago turned away from God ... and so they spend their time reading in the Black Book and practicing their evil deeds on poor, unsuspecting people. Instead of working, they spend their nights holding their black masses and dancing for the devil in the darkness of the river (99)

This unspoken accusation was made public when one of the witches died, after Ultima's intervention in the curse. When the funeral procession arrived, the priest "bar[red] entrance to the church ... [His] refusal meant the church was taking its stand and that the evil ways of the Trementinas were known to all" (141). For Antonio's family "[1]ittle d[id] [the Trementinas] care about church," their cries were "only to keep up appearances" (139). However, the questions of why the Trementina sisters, if they were really witches, cried and why they cared about having their sister buried in holy ground if they only answered to the Devil are still unanswered. In fact, the priest's denial to bury her and let her receive the mass was said to be due to their evil deeds, but no one openly says or proves those deeds are necessarily related to witchcraft.

The reader is once again presented with the representation of women, the prostitutes and the witches, who cannot describe themselves. As they do not own a voice or the voice they are given as characters misrepresents them, the negative image to which they are associated does not depend on them. It is the outside world the one that considers its right to judge and decide their roles in society, preventing as well good women to follow their lead. Moreover, the spaces these women inhabit, the brothel and the forest, are not liminal, but spaces considered by society as 'not proper' for women. As in the case of the Virgin-like characters, their lack of a liminal space and their connection, through the traditional society they live in, to a past in which only the role of the Virgin and Malinche are possible, unable them to appropriate any middle or liminal ground.

\section{ULTIMA, VIRGIN OR MALINCHE-LIKE CHARACTER?}

Although Ultima keeps her tradition and respects Catholicism, what could lead the reader to consider she symbolizes a Virgin-like character, she is also the guardian of magical practices, curanderismo 'folk medicine' and old religious beliefs, all of which could be related to a Malinche-like character. In his interpretation of liminality Turner considered "shamans, diviners [and] medium" (1974: 233) were mere outsiders. However, Ultima seems to be more than a shaman figure in this novel, what leads me to assent to define her as a proper individual. She is then a liminal character, someone who is "neither here nor there ... betwixt and between the positions assigned and arrayed by law, custom, convention, and ceremony" (Turner, 1969: 95).

In relation to her Virgin-like characteristics, Ultima's role as a curandera contrasts with her Catholic behaviour. Ultima uses religious expressions in her everyday language and 
keeps Catholic tradition, going to mass regularly and dressing "in black because so many women of the town had lost sons or husbands in the war and they were in mourning" (32). Robert Franklin Gish even claims that Ultima is a "flesh and blood incarnation of the Virgin ... because of her own miracles of healing and deliverance" (1996: 133). Nevertheless, the relationship she has with the Church and the priest is distant. In fact

[t]he church would not allow [her to] use [her] powers. ... The priest at El Puerto did not want the people to place much faith in the powers of la curandera. He wanted the mercy and faith of the church to be the villagers' only guiding light (97).

The negative nature her powers and her liminal role have for the traditional Catholic society are unveiled by the priest's attitude. He could not allow the villagers to follow the curandera's advice and her non-Catholic traditions. Moreover, her attitude as a woman who does not constrain to the fixed roles established could dangerously serve as an example for the pious and Virgin-like women of the village.

Antonio emphasises Ultima's mixture of Catholic beliefs and her role as a curandera when he refers to the end of her first communion scapular, where Ultima did not have the picture of the Virgin or St. Joseph but "[a] pouch of helpful herbs [that] keep you safe [and] will protect you from all evil" (124). When Ultima's traditions as a curandera blend with her Catholic rituals, her curandera nature seems to be stronger. After Antonio's birth "she carefully wrapped the useless cord and the afterbirth and laid the package at the feet of the Virgin on the small altar" (5), however, later on she removed Antonio's afterbirth from the feet of the Virgin to bury it: "I will bury the afterbirth and the cord that once linked him to eternity. Only I will know his destiny" (my emphasis) (6). In this way, her power over time and space exceeds the power of Catholic religious deities.

Moreover, although Ultima's blessings follow a Christian pattern, Antonio, when feeling Ultima's hand on his head, could also feel "a great force, like a whirlwind, swirl about [him]" (55). By analysing Ultima's contrastive figure, Antonio questions the nature of her power, asking himself if "the power of good and evil [was] the same" (55). In fact, despite this Catholic element in her blessings, what people usually ask Ultima for is her "blessing of safe return" (62). Hence, in most occasions, Ultima "blessed without using the name of the Trinity ..., and yet her blessing was as holy" (246).

Interestingly, the day Antonio goes to spend some time with his uncles his mother blesses him following the Catholic custom, but soon after, she kneels down and Ultima blesses them both in her own way. This significant double blessing points out the superiority of Ultima's powers over the powers of Catholicism, what distances her from the Virginlike characteristics and approaches her to the Malinche-like ones. Likewise, at the end of the novel, Ultima blesses Antonio using a final non-Catholic blessing that brings her even closer to a Malinche-like character in direct opposition to a pious, Catholic, Virgin-like one:

I bless you in the name of all that is good and strong and beautiful, Antonio. Always have the strength to live. Love life, and if despair enters your heart, look for me in the evenings when the wind is gentle and the owls sing in the hills. I shall be with you (261). 
When attending her Malinche-like characteristics, it is important to bear in mind that as a Chicana curandera, Ultima can be described as "a wise woman, a dispenser of curing herbs and potions who also heals with spiritual advice and some "magic"' (Shirley and Shirley 1988: 105). She represents a "shaman-figure" (Lee 2012: 118), but she is also described as a woman who has not sinned and as "[h]echicera, bruja ['witch']" (33). For Maria Luna, she is "a woman of learning ... [that] has worked hard for all the people of the village" (8), whereas Antonio's grandfather addresses her as "[m]édica ['doctor']” (91), emphasising the positive idea of the curandera as somebody who cures. However it is Ultima herself, by recognizing that "[ $\mathrm{t}]$ he people of the pueblo are nervous ... It has been many years since a curandera came to cure" (91), who opens up the possibility of associating curanderas with other activities, which could be or not related to evil.

Because a curandera "could exorcize the evil the witches planted in people to make them sick ... she was misunderstood and often suspected of practicing witchcraft herself" (4). Nonetheless, when Ultima accepts to cure Antonio's uncle, she distinguishes between witches and curanderas, as she respects God whereas witches turned away from God. The same as priest and sinner are opposite, brujas and curanderas seem to be antagonistic figures and Ultima claims to be on the right side, what would set her closer to the Virginlike characteristics despite her being a curandera. Nevertheless, Anaya provides several scenes in the novel that show Ultima lives in a liminal position.

One of the most representative scenes in which her in-between characteristics are clear is related to Ultima's ritual to cure Antonio's uncle. Before starting the ritual, Ultima goes to speak to Tenorio trying to reason with him. However, Tenorio calls Ultima 'bruja' and holds "the sign of the cross in front of Ultima's face" (93). At this point of the novel Antonio assures that this common knowledge remedy to stop a witch had not worked against Ultima, getting to the reasonable conclusion that "[e]ither she was not a bruja, or to their way of thinking, she had powers that belonged to the Devil himself" (93).

Although Ultima claims she is not a witch, she advises Tenorio to "understand the powers at work and how they can wreck the destinies of many lives" (my emphasis) (94). Since Tenorio's daughters did not lift the curse, this warning ends up leading way to the only solution Ultima sees, "work[ing] the magic beyond evil, the magic that endures forever" (94), and therefore to a direct menace in which Tenorio and his daughters should "[p]ity the consequence" (94) of their actions.

Ultima's ritual to save Antonio's uncle's life included mixing "many herbs and roots from her black bag [while s] he muttered as she stirred her mixture "the curse of the Trementinas shall bend and fly in their faces"' (97). The second part included molding three dolls:

She took from her black bag a large lump of fresh, black clay ... She broke it in three pieces, and she worked each one carefully ... she took the warm melted wax from the candle and covered the clay dolls with it ... she dressed the three dolls with scraps of cloth ... Then Ultima spoke to the three women: 'You have done evil ... But good is stronger than evil. And what you sought to do will undo you'... Then she took three pins, and after dipping them into the new remedy on the stove, she stuck a pin into each doll (101). 
In Ultima's balance of good and evil "good is always stronger" (98), so once again, she establishes that the power of witches is different from the power of a curandera. However, after her ritual two of the witches died and hence, the figure of the curandera seems to be again in the realms of liminality. She is a positive, good and caring figure with Antonio and her friends, but she can also prepare rituals to destroy her enemies, what connects her to Tenorio's wife. ${ }^{7}$

The second most important scene in which Ultima's liminal position comes to light is after the death of the first witch. Tenorio accuses Ultima of being a witch and convinces some men to hunt her and kill her, as tradition demanded. After Tenorio's accusation, " $[\mathrm{t}]$ he rest of the men ... [with] crosses of pins and needles they had pinned on their coats and shirts ... so that no curse might enter [them]" (131) cried that "if it is her curse that caused a death then she must be punished!" (132). Interestingly, Ultima's friends "do not question [Tenorio and his men's] right to charge someone with witchcraft, ${ }^{8}$ [as] it is so in custom" (132), which highlights once again that women were relegated to the two basic roles imposed to them by society, that of the good woman and that of the bad woman, in this case represented by a witch. No other role is possible and the existence of liminality is not even considered.

To solve any doubt about the nature of her powers Ultima is forced to pass a test that consists on taking two holy needles and pinning them to the top of the door frame; as tradition establishes "a witch cannot walk through the door so marked by the sign of Christ!" (133) because "her body burned with pain at the sight of the cross" (134). This test is another ritual depicting the biased role of women in society, as all men present agree that "[i]t is a true test ... It is legal in [their] customs [and they] have seen it work" (133). Ultima's ambiguous role is reinforced the moment she is about to cross, as her owl attacks Tenorio, distracting everybody's attention. When they all look back to Ultima,

[s] he had [already] walked through the door, [and although t]hey could not understand why the owl had attacked Tenorio; they could not understand the power of Ultima ... she had walked through the door, and so the power of la curandera was good, [leaving her] free of the accusation (134-135).

However, when the family walks into the house Anaya's portrayal of Ultima raises again the question of witchery, as he highlights how Antonio "paused at the door ... bent down and picked up the two needles.... Whether someone had broken the cross they made, or whether they had fallen, [he] would never know" (135).

Following her liminal position, it is relevant to address a third and last representative scene: the connection that exists between Ultima and her owl. Almost at the end of the novel the reader discovers that Ultima's owl is her protective spirit, "[t]he owl was her soul!" (255), emphasising again the barrier between Ultima's power and Catholicism. The owl is "a bird associated with the god of the netherworld in Aztec mythology and with Ultima in the novel [which] operates as an interesting fusion of contraries, both tutelary spirit

7 Tenorio's wife had been accused of witchery for molding dolls and using them against some villagers.

8 Although Anaya writes 'someone', only women were charged of that crime. Besides, not only anybody had the right to charge a woman with witchcraft but it was established as a tradition. 
and messenger of death" (Cazemajou 1988: 65) and contributes to Ultima's mysterious identification with it. Moreover, despite connecting this animal to the Western traditional concept of witches may seem obvious and may influence the unsolved debate of whether Ultima is a witch or not, Antonio insists that Ultima's owl is different:

In many cuentos ['tales'] I had heard the owl was one of the disguises a bruja took, and so it struck a chord of fear in the heart to hear them hooting at night. But not Ultima's owl. Its soft hooting was like a song, and as it grew rhythmic it calmed the moonlit hills and lulled us to sleep. Its song seemed to say that it had come to watch over us (13).

In fact, in Antonio's dreams Ultima's owl seems to be good in the eyes of the Catholic faith; in this way it is separated from witchcraft in the eyes of the reader, connecting Ultima once again to a Virgin-like character:

I dreamed about the owl that night, and my dream was good. ... I saw Ultima's owl lift la Virgen ['the Virgin'] on her wide wings and fly her to heaven. Then the owl returned and gathered up all the babes of Limbo and flew them up to the clouds of heaven. The Virgin smiled at the goodness of the owl (13).

When Tenorio discovers this inner connection he kills the owl expecting to kill Ultima. Nevertheless, the moment Ultima is about to die, she assures that "[t]he owl is ... [n]ot dead ... but winging its way to a new place, a new time" (260), what alludes to a religious reincarnation and leaves Ultima at a liminal position again.

This liminality lasts until the end of the novel, when Ultima explains to Antonio's father she does not want a Catholic burial ceremony: "She peered into the dying fire and smiled. ... Perhaps this would be the best burial you could provide me" (233). With this thought Ultima not only establishes she would rather be burnt than be buried in a cemetery, but his answer also shows Ultima is talking about not using a traditional Catholic casket: "I think the confines of a damp casket will bother me too. This way the spirit soars immediately into the wind of the llano, and the ashes blend quickly into the earth" (233). The closer the reader gets to the end of the novel, the closer Ultima's connection to witchcraft seems to be, as one of the so-called proofs that showed the Trementina sisters were witches was that they did not use a coffin, but a "basket woven of cottonwood branches" that would allow "the devil himself [to] come and sleep with the corpse before it is buried" (139).

However, Ultima's liminality is more present than ever: she will receive a mass and her body will be finally buried as a Christian at the cemetery in Las Pasturas, whereas her soul will be buried following a non-Catholic burial. Ultima asks Antonio to bury the owl under a forked juniper tree, what means burying Ultima's soul. Ultima's ideal burial and the burial of the owl are therefore depicted as another example of Ultima's liminality as a character, posing again the question of whether curanderismo and witchcraft could be addressed as separate concepts ${ }^{9}$.

9 The connection established between healers and witches date back to the centuries of witch burning in both Europe and North America, where control of population by religious authorities added to the fact that (female) healers posed a problem in a male-dominated occupation. 
Considering Turner's idea of liminality, Ultima rejoices in her liminal situation. She permanently lives in a liminal time and space: she escapes the 'proper' and 'not proper' spaces established for women, and she transcends time, connecting the past with the present and, more importantly, with the future.

\section{CONCLUSION: THE ROLE OF ULTIMA}

The dichotomy present for other women, who must choose between following the role of the Virgin or the role of Malinche, does not exist for Anaya's main female character. Ultima is in a liminal position where characteristics of the Virgin and Malinche interact and intertwine with one another and where she is full of "powerful, unknown magic" (147). As Gish explains "Ultima is at once comforting and courageous, surrogate mother and father; she is a curandera and bruja; spirit and person, human and animal; mortal and immortal, revered and feared" (1996: 126).

Anaya's main female character does not follow the mainstream, but brings together the old and the new, different religions and different cultures, for the hybrid and liminal Chicano community he is so determined to preserve. Anaya addressed this question explaining that "[1]iterature liberates. ... [As writers] [o]ur generation gave back to our community a way of viewing itself, and because we had been so oppressed it was a way of liberating self and community" (Kenyon 1989: 127).

Moreover, the narrator provides the reader with an image of Ultima as a strong, real role model who was able to "defeat evil where all else had failed" (255). Through Ultima, there are a challenge and a deconstruction of the constraining dichotomy Virgin vs. Malinche. Ultima's condition of in-betweenness leaves her in a position that opposes completely the roles established for female characters, and thus for women, by traditional patriarchal society.

Derrida established that "a text signifies in more than one way, and to varying degrees of explicitness" (Johnson 2004: xv); this is the case of Anaya's novel. Anaya acknowledges that for Mexican-American people this novel "became a mirror in which to reflect on the stable world of the past, a measure by which to view the future" (Gurpegui 2003: 69), but at the same time there is also a latent vindication of women's roles. Anaya only expressed having taken the world of female healers and "mov[ing] it a little bit into witchcraft to set up the conflict between good and evil" (Stone 2007). Nonetheless, in her study of Anaya, Margarite Fernández Olmos claims that in Rio Grande Fall, published after Bless Me, Ultima,

[t]hrough the character of Lorenza Villa, Rudolfo Anaya redeems the twentieth-century, multicultural female healer. Far from a figure to be feared or vilified, Lorenza's psychic abilities are used for good; her faculties are life affirming. Lorenza represents a vital female culture that contributes to the community; she is a resource, a trained specialist who uses her knowledge and talent to strengthen others and herself (1999: 133),

which reinforces my interpretation of Anaya's use of Ultima's liminal position as a way of consciously redefining female roles. By including a strong and powerful character like Ultima, he contributes to recover a positive image for Chicanas. Ultima's role as a reminder 
of the past, the history, the myths and the language helps society to find, establish or recover a Chicano/a collective identity. Moreover, since liminality "is essentially subversive" (Grobler, De Lange and Wenzel 2015: 1), through her liminal self, "betwixt and between" (Turner, 1969: 95) the roles of the Virgin and Malinche, Ultima also becomes a feminist character, central to the construction of new forms of identity for women, and entails the emergence of agency and empowerment in the Chicana readers.

This character is a pioneer in the process of signifying a voice and spurring critical questions, by which later on Chicana "writer[s] and reader[s] [have been] breaking out of silence, no longer [have] they [been] mere presences, but instruments for change, visionaries awakening the people" (Sánchez 1997: 67). By creating a liminal figure, worshipped by some and despised by others, and placing her as the key character in the story Anaya rewrites the legend of Malinche and the Virgin and provides his community with the epitome of the deconstruction of women's roles. In this liminal space Ultima is able to embrace the different aspects that mould her identity. She does not need to leave anything apart. Ultima shows the reader that.

Rigidity means death. Only by remaining flexible is she able to stretch the psyche horizontally and vertically.... The new mestiza copes by developing a tolerance for contradictions, a tolerance for ambiguity. She learns to be an Indian in Mexican culture, to be Mexican from an Anglo point of view. She learns to juggle cultures. She has a plural personality, she operates in a pluralistic mode - nothing is thrust out, the good the bad and the ugly, nothing rejected, nothing abandoned (Anzaldúa 1987: 79).

Chicanas can no longer be constrained to the identities established by the dominant culture but they can appropriate new practices and identities through the creation or acceptance of their own liminal selves.

\section{REFERENCES}

Alarcón, N. 1981. “Chicana’s Feminist Literature: A Re-Vision Through Malintzin/ or Malintzin: Putting the Flesh Back on the Object." This Bridge Called My Back: Writings by Radical Women of Color. Ed. C. Moraga and G. Anzaldúa. Watertown, MA: Persephone. 182-190.

AnAYA, R. 1984. The Legend of La Llorona, a Short Novel. Berkeley: Tonatiuh-Quinto Sol International.

----. 1994. Bless Me, Ultima. New York: Warner Books.

---. 1997. Maya's Children: The Story of La Llorona. New York: Hyperion Books.

---- 2011. La Llorona: The Crying Woman. Albuquerque: University of New Mexico Press.

Annenberg Foundation. 2014. "Exploring Borderlands. American Passages (A literary survey)." Learner. 23 Feb. 2014. http://learner.org/amerpass/unit02/index.html.

AnzaldúA, G. 1987. Borderlands / La Frontera: The New Mestiza. San Francisco: Aunt Lute Books. 
Beekman Taylor, P. 1997. "Chicano Secrecy in the Fiction of Rudolfo A. Anaya." Journal of the Southwest 39, 2: 239-265.

Benítez Eyzaguirre, L. 2007. "Mujeres Migrantes Africanas en Busca de Identidad: El Camino de la Literatura." Afroeuropa: Journal of Afroeuropean Studies 1, 1. 24 July 2008. http://journal.afroeuropa.eu/index.php/afroeuropa/article/view/6/9.

Caminero-Santangelo, M. 1999. "Beyond Otherness: Negotiated Identities and Viramontes." "The Cariboo Cafe." Women on the Edge. Ethnicity and Gender in Short Stories by American Women. Ed. C. H. Dale and J. H. E. Pain. New York / London: Garland Publishing Inc. 19-34.

Candelaria, C. 2002. "La Malinche, Feminist Prototype." Chicana Leaderships: The Frontiers Reader. Ed. Y. Flores Niemann, S. H. Armitage, P. Hart and K. Weathermon. Lincoln / London: University of Nebraska Press. 1-14.

Cazemajou, J. 1988. "Mediators and Mediation in Rudolfo Anaya's Trilogy: Bless Me, Ultima, Heart of Aztlan and Tortuga." European Perspectives on Hispanic Literature of the United States. Ed. G. Fabre. Houston: Arte Publico. 55-65.

Cotera, M. 1997. "Feminism: The Chicano and Anglo Versions - A Historical Analysis." Chicana Feminist Thought. The Basic Historical Writings. Ed. A. M. García. New York: Routledge. 223-231.

Derrida, J. 2004. Dissemination. Transl. Barbara Johnson. New York: Continuum.

Fernández Olmos, M. 1999. Rudolfo A. Anaya: A Critical Companion. Westport: Greenwood.

Gilsenan Nordin, I. \& Holmsten, E. 2009. Liminal Borderlands in Irish Literature and Culture. Bern: PeterLang.

Gish, R. F. 1996. Beyond Bound: Cross-cultural essays on Anglo, American Indian and Chicano Literature. Albuquerque: New Mexico UP.

Grobler, A., De Lange, A. M. \& Wenzel, M. J. 2015 . "Liminality in J. M. Coetzee's later experimental texts." Literator 36, 1.24 May 2016. dx.doi.org/10.4102/lit.v36i1.1167.

Gurpegui, J.A. 2003. Narrativa Chicana: Nuevas Propuestas Analíticas. Madrid: Instituto Universitario de Estudios Norteamericanos de la Universidad de Alcalá.

Holton, F. S. 1995. "Chicano as "Bricoleur”: Christianity and Mythmaking in Rudolfo Anaya's "Bless Me, Ultima." Confluencia. 11, 1: 22-41.

Johnson, B., transl. 2004. Dissemination. J. Derrida. New York: Continuum.

Jussawalla, F. \& Dasenback, R. W. 1997. "Interview with Sandra Cisneros." Chicana Feminist Thought. The Basic Historical Writings. Ed. A. M. García. New York: Routledge. 287-289.

KÁRAi, A. 2008. "The Postmodern Use of Mythopoeia in the Narrative Temporality of Rudolfo Anaya's "Bless Me, Ultima." Hungarian Journal of English and American Studies 14, 2: 265-285. 
Karrer, W. 2001. "Postcolonial Identity Politics in Chicano Movement Rhetoric and Literature.” AZTLÁN. Ensayos sobre literatura chicana. Ed. F. Eguíluz, A. Ibarraran, $M^{a}$ F. López Liquete and D. Río. Bilbao: País Vasco UP. 129-142.

KatraK, K. H. 1995. “Decolonizing Culture. Toward a Theory for Post-colonial Women's Texts." The Post-colonial Studies Reader. Ed. B. Ashcroft, G. Griffiths and H. Tiffin. London: Routledge. 255-258.

KenYon, K. 1989. "Visit with Rudolfo Anaya.” Confluencia 5, 1: 125-127.

KLEIN, D. 1992. "Coming of Age in Novels by Rudolfo Anaya and Sandra Cisneros.” The English Journal 81, 5: 21-26.

LeE, A. R. 2012. "Multiethnicities: Latino/a and Asian American fiction.” The Cambridge Companion to American Fiction After 1945. Ed. J. N. Duvall. Cambridge: Cambridge UP. 114-128.

Mirandé, A. \& EnríQuez, E. 1979. La Chicana: The Mexican-American Woman. Chicago: Chicago UP.

Morillas SÁnchez, R. 2000. "Out of the 'barrio': breaking the myth of chicana women in Cisneros' The House on Mango Street." Literatura Chicana. Reflexiones y Ensayos Críticos. Ed. R. Morillas Sánchez and M. Villar Raso. Granada: Comares. 273-282.

Morris, P. 1995. Literature and Feminism: An Introduction. Oxford: Blackwell.

Pentecost, R. A. 2014. "Indigenous and Spanish Transculturation: Becoming Mexican American." Plaza: Dialogues in Language and Literature 5, 1: 39-47. 05 July 2015. http://journals.tdl.org/plaza/index.php/plaza/article/download/7055/pdf_13.

Perles Rochel, J.A. 1994. Una propuesta de revisión del feminismo ginocéntrico a través de la narrativa chicana: Sandra Cisneros, Montserrat Fontes y Rudolfo A. Anaya. Málaga: Universidad de Málaga.

Rogers, J. 1977. "The Function of the "La Llorona" Motif in Rudolfo Anaya's "Bless Me, Ultima." Latin American Literary Review 5, 10: 64-69. Special Issue of Chicano Literature.

SÁnchez, R. 1997. "Chicana Writer Breaking Out of the Silence.” Chicana Feminist Thought. The Basic Historical Writings. Ed. A. M. García. New York: Routledge. 66-68.

Shirley, C. R. \& ShIRley, P. W. 1988. Understanding Chicano Literature. Columbia: South Carolina UP.

Stone, D. 2007. "An Interview with Rudolfo Anaya." The National Endowment for the Arts and the Institute of Museum and Library Services and Arts Midwest. 11 Jan. 2012. http://www.neabigread.org/books/blessmeultima/readers-guide/about-the-author/.

Turner, V. 1967. "Betwixt and Between: The Liminal Period in Rites de Passage." The Forest of Symbols: Aspects of Ndembu Ritual. Ithaca: Cornell University Press.

---- 1969. “Liminality and Communitas.” The Ritual Process: Structure and Anti-Structure. Chicago: Aldine. 
----. 1974. "Passages, Margins, and Poverty: Religious Symbols of Communitas.” Dramas, Fields, and Metaphors. In C. La Shure. 2005. What is Liminality? PhD thesis. Seoul National University. 22 Oct. 2015. http://www.liminality.org/about/whatisliminality/. Van Gennep, A. 1960. The Rites of Passage. London: Routledge.

Yarbro-Bejarano, Y. 1996. "Chicana Literature from a Chicana Feminist Perspective." Chicana Creativity and Criticism. New Frontiers in American Literature. Ed. M. Herrera-Sobek and H. M. Viramontes. Albuquerque: New Mexico UP. 213-219. 